\title{
Determinación de parámetros CINÉTICOS Y operacionales para el diseño de un reactor UASB a escala real
} Determination of kinetic and operational parameters for full-scale uasb design

\author{
Angel Luis Santiago Díaz \\ Universidad Autónoma Metropolitana, México \\ angel.santiago2@upr.edu \\ Icela Dagmar Barceló Quintal \\ Universidad Autónoma Metropolitana, México \\ ibarceloq@gmail.com \\ Mónica Liliana Salazar Pelaez \\ Universidad Autónoma Metropolitana, México \\ monsalazarp@gmail.com
}

\section{Resumen}

El objetivo de este trabajo fue determinar la constante de velocidad (K), los coeficientes de rendimiento celular (Y) y de decaimiento endógeno (ke) y algunos parámetros operacionales para el diseño de un reactor UASB a escala real para el tratamiento de las aguas residuales municipales generadas en el campus de la Universidad Autónoma Metropolitana - Azcapotzalco. Para este fin, un reactor UASB a escala de laboratorio fue operado bajo cuatro TRH diferentes $(4,6,8$ y 12 h) durante seis meses. La remoción de la DQO total varió entre $50 \%$ al TRH de 4 horas hasta un 75\% al TRH de 12 horas, se obtuvieron resultados similares con los parámetros de DBO5 y SST. Una prueba t de Student apareada mostró que la remoción de DQO obtenida con los cuatro TRH estudiados fue significativamente diferente al TRH de 12 horas; por lo tanto, se recomienda este TRH para el diseño del reactor UASB a escala real. La constante de velocidad $(\mathrm{K})$ a $21{ }^{\circ} \mathrm{C}$ fue $8 \times 10^{-5} \mathrm{~L} / \mathrm{mg} \mathrm{SSV}-\mathrm{d}$, basado en la soluble $\mathrm{DBO}_{5}$ y 3 x $10^{-5}$ L / mg SSV - d basado en la DQO soluble, estos valores son considerados bajos, lo que indica la presencia de una cantidad importante de compuestos orgánicos de difícil degradación, probablemente procedentes de las aguas residuales generadas en los laboratorios universitarios. Los coeficientes cinéticos fueron $\mathrm{Y}=0.0427 \mathrm{mg}$ $\mathrm{SSV} / \mathrm{mg} \mathrm{DBO}_{5}$ y $\mathrm{k}_{\mathrm{e}}=0.02 \mathrm{~d}^{-1}$ basado en la $\mathrm{DBO}_{5}$ soluble como sustrato y $\mathrm{Y}=0.0596 \mathrm{mg} \mathrm{SSV} / \mathrm{mg} \mathrm{DQO}$ y $\mathrm{k}_{\mathrm{e}}=$ $0.04 \mathrm{~d}^{-1}$ basado en la DQO soluble como sustrato. El tiempo medio de residencia celular $\left(\theta_{\mathrm{C}}\right)$ en el reactor UASB a 
escala de laboratorio fue de 49.5 días, aunque se recomienda un $\theta_{C}$ de 99 días para el diseño del reactor UASB a escala real.

Palabras clave: Agua residual municipal, Coeficientes cinéticos, degradación anaerobia.

\section{Abstract}

The aim of this study was to determine the rate constant (K) coefficients cell yield (Y) and endogenous decay (ke) and some operational parameters for the design of a UASB reactor-scale for water treatment residual municipal generated on the campus of the Universidad Autonoma Metropolitana - Azcapotzalco. To this end, a UASB reactor laboratory scale was operated under four different TRH (4, 6,8 and $12 \mathrm{~h})$ for six months. The removal of total COD ranged from $50 \%$ to HRT of 4 hours to $75 \%$ at HRT of 12 hours, similar results were obtained with the parameters of BOD5 and TSS. A Student's t test paired showed that the COD removal obtained with the four TRH studied was significantly different from HRT than 12 hours; therefore, it is recommended that TRH for design UASB-scale. The rate constant $(\mathrm{K})$ at $21^{\circ} \mathrm{C}$ was $8 \times 10-5 \mathrm{~L} / \mathrm{mg}$ SSV - $\mathrm{d}$, based on the BOD5 soluble and $3 \times 10-5 \mathrm{~L} / \mathrm{mg} \mathrm{SSV}-\mathrm{d}$ based on the soluble COD, these values are considered low, indicating the presence of a significant amount of organic compounds of difficult degradation, probably from the wastewater produced in university laboratories. The kinetic coefficients were $\mathrm{Y}=0.0427 \mathrm{mg}$ SSV $/ \mathrm{mg}$ BOD5 and $\mathrm{ke}=0.02 \mathrm{~d}-1$ based on soluble BOD5 as substrate and $\mathrm{Y}=0.0596 \mathrm{mg} \mathrm{SSV} / \mathrm{mg}$ COD and $\mathrm{ke}=0.04 \mathrm{~d}-1$ based on the soluble COD as substrate. The average time of cell residence $(\theta \mathrm{C})$ in the UASB reactor at laboratory scale was 49.5 days, although it recommends a $\theta \mathrm{C}$ of 99 days for the reactor design UASB-scale.

Key words: Anaerobic degradation, Kinetic coefficients, Municipal wastewater

Fecha Recepción: Mayo 2015 Fecha Aceptación: Noviembre 2015 


\section{INTRODUCTION}

The up-flow anaerobic sludge blanket (UASB) reactors have proven to be a viable and sustainable technology for the treatment of municipal wastewater in developing countries and small communities based on their low investment, operation and maintenance costs (Foresti et al., 2006; Khan et al., 2011). As a result, most of the fullscale municipal UASB reactors have been installed in India and Latin-America, and, by 2004 more than 50 installations had been reported (WEF et al., 2010).

Conversely, design and operation of these facilities with municipal wastewater remains limited at regions with warmer temperature; and, consequently, limited design and performance data are available regarding UASB performance for treatment of municipal wastewater (WEF et al., 2010).

On the other hand, historically, the stability and performance of anaerobic treatment systems have been considered poor in comparison to aerobic systems. However, with improved understanding of the factors that affect their performance, it has been possible to obtain a stable and reliable performance (Leslie Grady et al., 2003). Hence, even with an increasing number of full-scale UASB installations, a thorough characterization of wastewater is essential and lab and pilot testing is desirable, before a new UASB be installed (Henze et al., 2008).

Thus, the objective of this work was to determine the rate constant $(\mathrm{K})$, the cell yield $(\mathrm{Y})$ and the endogenous decay $\left(\mathrm{k}_{\mathrm{e}}\right.$ ) coefficients and some operational parameters for the design of a full-scale UASB for the treatment of municipal wastewater generated at the Universidad Autónoma Metropolitana - Azcapotzalco campus through an experiment where a lab-scale UASB reactor was operated under four different hydraulic retention times (HRT).

\section{MATERIALS AND METHODS}

\subsection{Experimental Set Up}

A lab scale UASB reactor $(6.1 \mathrm{~L}$ volume, $\mathrm{PVC})$ was inoculated with sludge from a full-scale UASB reactor treating brewery wastewater. The municipal wastewater was obtained after primary sedimentation in the wetland system constructed at the Metropolitan Autonomous University - Azcapotzalco Campus and pumped to the UASB reactor using a peristaltic pump (Model Masterflex 7553-30, Cole-Parmer, USA). Temperature in the UASB reactor was maintained at $21 \pm 1{ }^{\circ} \mathrm{C}$ during the experiment. The UASB reactor was operated until acclimated sludge was developed (approx. 2 months). The end of the acclimation period was determined by measuring the organic substrate concentration in the effluent; once this parameter reached the minimum value, the sludge in the reactor was considered acclimated. After acclimation was attained, the reactor was operated at steady state under four different 
hydraulic retention times (HRT): 4, 6, 8 and 12 hours, during one month each HRT, and the information necessary to calculate the rate constant and the kinetics coefficients was obtained. During the experiment was not carry out any discharge of sludge, other than the volatile suspended solids (VSS) present in the effluent.

\subsection{Analytical Methods}

$\mathrm{pH}$, temperature, dissolved oxygen (DO) and oxidation-reduction potential (ORP) were measured daily in the UASB reactor influent and effluent using an ion specific electrode (ISE) for each parameter (Model LabQuest, Vemier, USA). Total suspended solids (TSS), volatile suspended solids (VSS), total and soluble chemical oxygen demand (COD), biological oxygen demand (BOD5) and alkalinity were measured twice per week according to the Standard Methods (1998). The ratio between partial and total alkalinity (PA/TA ratio) was calculated according to Soto et al. (1993).

\subsection{Rate constant and kinetic coefficients determination}

In the design of UASB reactors based on the Monod and Michaelis-Menten relationships, it is necessary to use equations that employ the following parameters:

$>\mathrm{K}=$ Rate constant considering a pseudo-first order reaction ( $\mathrm{mg} \mathrm{COD}$ or $\mathrm{BOD} / \mathrm{mg} \mathrm{VSS}-\mathrm{d}$ )

$>\mathrm{Y}=$ Cell yield coefficient (mg VSS / mg COD or BOD removed)

$>\mathrm{k}_{\mathrm{e}}=$ Endogenous decay coefficient $\left(\mathrm{d}^{-1}\right)$

$\mu=$ Growth coefficient $\left(\mathrm{d}^{-1}\right)$

$>\mu_{\max }=$ maximum value of the growth coefficient $\left(\mathrm{d}^{-1}\right)$

$>\mathrm{Ks}=$ Substrate concentration with $\mu=\frac{1}{2} \mu_{\max }(\mathrm{mg} / \mathrm{LCOD}$ or BOD)

According to Reynolds \& Richards (1996), it is not valid to assume a Y value and a ke value and knowing other parameters, as substrate removal and biomass concentration, to calculate the reactor mean cell residence time $\left(\theta_{c}\right)$. For the usual case, the substrate concentration in the effluent is known, and $\mu_{\max }, \mathrm{K}_{\mathrm{s}}, \mathrm{Y}$ and $\mathrm{k}_{\mathrm{e}}$ are determined from kinetic studies. Thus, the required $\theta_{c}$ can be determined using kinetic equations.

It is possible to obtain the reaction rate constant $(\mathrm{K})$ and the cell yield $(\mathrm{Y})$ and the endogenous decay $\left(\mathrm{k}_{\mathrm{e}}\right)$ coefficients from one continuous-flow reactor operated at three or more food/microorganism (F/M) ratios during equal periods to conserve time (Reynolds \& Richards, 1996). 
The rate constant $(\mathrm{K})$, is determined from eq. 2.1, which is based on the Monod equation, assuming that the substrate concentration is relatively small and a pseudo-first order reaction (Reynolds \& Richards, 1996):

$$
\frac{S_{i}-S_{t}}{X \theta_{i}}=K S_{t}
$$

Where

$>\mathrm{S}_{\mathrm{i}}=$ Influent substrate concentration $(\mathrm{mg} / \mathrm{LCOD}$ or BOD)

$>\mathrm{S}_{\mathrm{t}}=$ Effluent substrate concentration (mg/LCOD or BOD)

$>\mathrm{X}=$ Biomass concentration $(\mathrm{mg} / \mathrm{L}$ VSS)

$>\theta_{\mathrm{i}}=$ Hydraulic retention time $(\mathrm{d})$

$\mathrm{K}=$ Rate constant $(\mathrm{L} / \mathrm{mg} \mathrm{COD}$ or BOD $-\mathrm{d})$

Plotting the $S_{\mathrm{t}}$ values on $x$-axis and $\frac{S_{i}-S_{t}}{x \theta_{i}}$ on $y$-axis, will give a straight line if the biochemical reaction is pseudo-first order. The slope of this line is equal to the rate constant $(\mathrm{K})$.

According to Reynolds \& Richards (1996), the cell yield coefficient (Y) considers the portion of substrate converted to new cells; while the endogenous decay coefficient $\left(\mathrm{k}_{\mathrm{e}}\right)$ accounts for the loss in cell mass due to oxidation of internal storage products for energy for cell maintenance, cell death and predation by organisms higher in the food chain, and, it appears to change with cell age. Kinetic coefficients can vary as a function of the wastewater source, the class of organic compounds degraded, the concentration of inert solids in wastewater, the COD converted to methane, the microbial population and temperature (WEF et al., 2010).

The coefficients $\mathrm{Y}$ and $\mathrm{k}_{\mathrm{e}}$ may be determined from one continuous-flow reactor operated under different HRT, using the relation that exists between substrate utilization and cell production, according to eq. 2.2 (Reynolds \& Richards, 1996):

$\frac{d X}{d t}=Y \frac{d S}{d t}-k_{e} X$

Where

$>\mathrm{dX} / \mathrm{dt}=$ rate of cell production $(\mathrm{mg} \mathrm{VSS} / \mathrm{L}-\mathrm{d})$

Y $\mathrm{Y}=$ Cell yield coefficient (mg VSS / mg COD or BOD removed)

$\mathrm{k}_{\mathrm{e}}=$ Endogenous decay coefficient $\left(\mathrm{d}^{-1}\right)$ 
$>\mathrm{ds} / \mathrm{dt}=$ Rate of substrate utilization $(\mathrm{mg}$ COD or BOD $/ \mathrm{d}$ )

$>\mathrm{X}=$ Biomass present inside biological reactor (mg VSS)

Dividing by $\mathrm{X}$ and using measurable increases during a determined period of time, eq. 2.2 gives eq. 2.3:

$\frac{\Delta X / \Delta t}{X}=\frac{Y}{X} * \frac{\Delta S}{\Delta t}-k_{e}$

Where

$\Delta \mathrm{X}=$ Change in the cell mass concentration (mg/L VSS)

$>\Delta \mathrm{t}=$ Time increment $(\mathrm{d})$

D $=$ Average cell concentration during the time increment (mg/L VSS)

The coefficients $\mathrm{Y}$ and $\mathrm{k}_{\mathrm{e}}$ may be calculated by a modification of eq. 2.3 , which is:

$\frac{\Delta X / \Delta t}{X}=Y\left(\frac{S_{i}-S_{t}}{X \theta_{i}}\right)-k_{e}$

Plotting the $\left(\frac{S_{i}-S_{t}}{X \theta_{i}}\right)$ values on $x$-axis and $\frac{\Delta X / \Delta t}{X}$ on $y$-axis, will give a straight line with the slope equal $Y$ and $y$-axis intercept equal to $\mathrm{k}_{\mathrm{e}}$.

To determine the rate constant $(\mathrm{K})$ and the coefficients $\mathrm{Y}$ and $\mathrm{k}_{\mathrm{e}}$ in UASB reactor, were employed the values of soluble $\mathrm{COD}$ and $\mathrm{BOD}_{5}$ from UASB reactor influent and effluent under the four different HRT studied.

\subsection{Determination of the mean cell residence time in UASB reactor}

According to Tchobanoglous et al. (2003), a mass balance on the inert material in the biological reactor yields:

$$
\left[\begin{array}{c}
\text { Accumulation of } \\
\text { inert material } \\
\text { in UASB reactor }
\end{array}\right]=\left[\begin{array}{c}
\text { Inflow of } \\
\text { inert material } \\
\text { in UASB reactor }
\end{array}\right]-\left[\begin{array}{c}
\text { Outflow of } \\
\text { inert material } \\
\text { in UASB reactor }
\end{array}\right]+\left[\begin{array}{c}
\text { Generation of } \\
\text { inert material } \\
\text { in UASB reactor }
\end{array}\right]
$$

This mass balance can be expressed as follows:

$\frac{d_{X_{i}}}{d t}=Q X_{i n f}+r_{X_{i}} V-\frac{V X_{i}}{\theta_{c}}$ 
Where:

$>\mathrm{X}_{\mathrm{i}}=$ Nonbiodegradable VSS in UASB reactor $(\mathrm{mg} / \mathrm{L} \mathrm{VSS})$

$>\mathrm{X}_{\mathrm{inf}}=$ Nonbiodegradable VSS in influent $(\mathrm{mg} / \mathrm{L}$ VSS)

$\mathrm{r}_{\mathrm{xi}}=$ Rate of nonbiodegradable VSS from cell debris (mg VSS / L - d)

$>\mathrm{V}=$ Volume of reactor $(\mathrm{L})$

$>\mathrm{Q}=$ Wastewater flowrate $(\mathrm{L} / \mathrm{d})$

$>\theta_{\mathrm{C}}=$ Mean cell residence time $(\mathrm{d})$

The rate of nonbiodegradable VSS (nbVSS) from cell debris $\left(\mathrm{r}_{\mathrm{xi}}\right)$ is the eq. 2.6:

$r_{X_{i}}=f_{e} k_{e} X V$

Where

$\mathrm{fe}=$ Fraction of biomass that remains as cell debris (mg SSV / g SSV)

Combining eq. 2.6 and eq. 2.5 and considering that no exists accumulation of inert material inside UASB reactor, the eq. 2.7 is obtained:

$0=Q X_{\text {inf }}+f_{e} k_{e} X V-\frac{V X_{i}}{\theta_{C}}$

If eq. 2.7 is solved for $\mathrm{X}_{\mathrm{i}}$ :

$X_{i}=\frac{X_{\text {inf }} \theta_{C}}{T R H}+f_{e} k_{e} X \theta_{C}$

On the other hand, biomass concentration $(X)$ may be calculated using eq. 2.9:

$X=\frac{Y\left(S_{i}-S_{1}\right)}{\left(1+k_{e} \theta_{c}\right)} * \frac{\theta_{C}}{T R H}$

And combining eq. 2.8 and eq. 2.9, will give the solids production $\left(\mathrm{X}_{\mathrm{T}}\right)$ as follows:

$X_{T}=\frac{Y\left(S_{i}-S_{1}\right)}{\left(1+k_{e} \theta_{c}\right)}+f_{e} k_{e} X V+X_{\text {inf }}$

Where

$\mathrm{X}_{\mathrm{T}}=$ Net VSS production per day (mg/d VSS) 
The first term of eq. 2.10 is related with solids production of heterotrophic biomass; meanwhile the second and third terms are related with cell debris and non biodegradable VSS in the influent, respectively.

Eq. 2.10 can be modified to calculate the solids production in terms of TSS, assuming a typical biomass VSS/TSS ratio of 0.85 . This ratio may vary from 0.8 to 0.9 .

$X_{T, S S T}=\frac{Y\left(S_{i}-S_{1}\right)}{\left(1+k_{e} \theta_{c}\right) * 0.85}+\frac{f_{e} k_{e} X V}{0.85}+X_{\text {inf }}$

Where

$>\mathrm{X}_{\mathrm{TSST}}=\mathrm{TSS}$ production per day $(\mathrm{mg} / \mathrm{d} \mathrm{TSS})$

Combining eq. 2.9 and eq. 2.11, yields eq. 2.12 :

$X_{T, S S T}=\frac{Y\left(S_{i}-S_{1}\right)}{\left(1+k_{e} \theta_{c}\right) * 0.85}+\frac{f_{e} k_{e} Y\left(S_{i}-S_{1}\right)}{\left(1+k_{e} \theta_{c}\right) * 0.85}+X_{\text {inf }}$

Eq. 2.12 was employed to calculate the mean cell residence time $\left(\theta_{C}\right)$ of the UASB reactor. In this equation was considered that TSS production per day $\left(\mathrm{X}_{\mathrm{T}, \mathrm{SST}}\right)$ was equal to TSS concentration in UASB reactor effluent, due to during the experiment was not carry out any discharge of sludge.

Then, eq. 2.12 was solved for $\theta_{\mathrm{C}}$ using the coefficients $\mathrm{Y}$ and $\mathrm{k}_{\mathrm{e}}$, obtained according to the procedure explained in section 2.3, and the values of soluble $\mathrm{COD}$ and $\mathrm{BOD}_{5}$ from UASB reactor influent and effluent. A $\theta_{\mathrm{C}}$ value was obtained for each one of the four different HRT studied.

\section{RESULTS AND DISCUSSION}

\subsection{UASB reactor performance}

Table 1 shows the results obtained for the different parameters analyzed in the influent during the experiment, meanwhile Table 2 shows the results obtained in the UASB effluent.

Table 2 shows that $\mathrm{pH}$ values in UASB effluent followed the influent tendency. $\mathrm{pH}$ values in municipal wastewater were between 7.5 and 9, which are higher than those that usually occurs in municipal wastewater; this could be associated with the fact that sewage in the university campus also collects the wastewater generated in laboratories.

On the other hand, $\mathrm{pH}$ in UASB reactor was slightly basic (between 7.3 and 8.7) throughout the entire experiment, which is adequate for UASB reactor operation (van Haandel \& Lettinga, 1994). According to Galli and McCarty 
(1989), methanogenesis occurs with ORP values below than $-170 \mathrm{mV}$, therefore the atmosphere inside the UASB reactor was suitable for methane production.

Total alkalinity values were higher during acclimation and $12 \mathrm{~h} \mathrm{HRT}$ than in the period where the UASB reactor was operated under 6, 8 and 12 hours, following the tendency of UASB influent; however, this fact did not represent a sign of instability since the partial and total alkalinity ratio (PA/TA) was $0.95 \pm 0.02$. According to Soto et al. (1993), the PA/TA ratio is a parameter that allows the monitoring VFA accumulation inside anaerobic reactors and it must be maintained near from 1 in order to prevent acidification.

Table 1.

Results for the different parameters analyzed at the UASB reactor influent

\begin{tabular}{|c|c|c|c|c|c|}
\hline \multirow{2}{*}{ Parameter } & \multirow{2}{*}{ Acclimation } & \multicolumn{4}{|c|}{ HRT (hours) } \\
\hline & & 12 & 8 & 6 & 4 \\
\hline $\mathrm{pH}$ & $8.6 \pm 0.30$ & $8.5 \pm 0.33$ & $9.17 \pm 0.15$ & $8.88 \pm 0.35$ & $8.97 \pm 0.293$ \\
\hline $\mathrm{T}\left({ }^{\circ} \mathrm{C}\right)$ & $22 \pm 0.87$ & $21.1 \pm 0.16$ & $21.4 \pm 0.58$ & $20.21 \pm 0.83$ & $20.33 \pm 0.96$ \\
\hline $\mathrm{ORP}(\mathrm{mV})$ & -239.6 & $-237.62 \pm 51.5$ & $-224.8 \pm 20.71$ & $-207.33 \pm 38.17$ & $-227.61 \pm 49.52$ \\
\hline $\mathrm{DO}(\mathrm{mg} / \mathrm{L})$ & $0.42 \pm 0.25$ & $0.15 \pm 0.17$ & $0.19 \pm 0.15$ & $0.26 \pm 0.21$ & $0.19 \pm 0.21$ \\
\hline $\begin{array}{l}\text { Alkalinity } \\
\left(\mathrm{mg} / \mathrm{LCaCO}_{3}\right)\end{array}$ & $218.2 \pm 29.5$ & $217.06 \pm 38.5$ & $134.87 \pm 30.9$ & $102.23 \pm 20.3$ & $144.75 \pm 24.5$ \\
\hline Total COD(mg/L) & $640 \pm 195.6$ & $639.53 \pm 200.66$ & $366.26 \pm 112.32$ & $268.55 \pm 73.8$ & $407 \pm 123.7$ \\
\hline Soluble COD(mg/L) & $339 \pm 117.45$ & $338.7 \pm 129.17$ & $213.88 \pm 58.22$ & $147.70 \pm 42.45$ & $257.23 \pm 67.38$ \\
\hline $\begin{array}{l}\text { Soluble BOD5 } \\
(\mathrm{mg} / \mathrm{L})\end{array}$ & $140.1 \pm 6.01$ & $207 \pm 48.08$ & $181.25 \pm 76.72$ & $209.5 \pm 2.12$ & $138 \pm 14.14$ \\
\hline Total carbon (mg/L) & $326.9 \pm 73.4$ & $211.72 \pm 43.39$ & $138.86 \pm 39.09$ & $216.99 \pm 77.8$ & $167.06 \pm 17.05$ \\
\hline $\begin{array}{l}\text { Organic carbon } \\
(\mathrm{mg} / \mathrm{L})\end{array}$ & $180 \pm 63.2$ & $58.9 \pm 43.25$ & $19.85 \pm 9.7$ & $59.37 \pm 54.40$ & $24.70 \pm 16.15$ \\
\hline TS (mg/L) & $1066 \pm 168.2$ & $1065.83 \pm 116.5$ & $788.01 \pm 339.5$ & $922.7 \pm 171.3$ & $1084.01 \pm 38.15$ \\
\hline TSS (mg/L) & $696 \pm 43.2$ & $695.1 \pm 288.43$ & $573.34 \pm 255.5$ & $740 \pm 113.4$ & $806.67 \pm 31.06$ \\
\hline VSS (mg/L) & $371 \pm 165$ & $370.6 \pm 231.35$ & $214.6 \pm 85.4$ & $182.67 \pm 70.01$ & $277.34 \pm 14.04$ \\
\hline
\end{tabular}


Table 2.

Results for the different parameters analyzed at the UASB reactor effluent

\begin{tabular}{lccccc}
\hline \multicolumn{1}{c}{ Parameter } & Acclimation & $\mathbf{1 2}$ & $\mathbf{8}$ & $\mathbf{6}$ & $\mathbf{4}$ \\
\hline $\mathrm{pH}$ & $8.4 \pm 0.18$ & $8.034 \pm 0.16$ & $8.38 \pm 0.25$ & $8.20 \pm 0.11$ & $8.40 \pm 0.22$ \\
$\mathrm{~T}\left({ }^{\circ} \mathrm{C}\right)$ & $21.3 \pm 0.19$ & $21.72 \pm 0.17$ & $21.53 \pm 0.51$ & $21.84 \pm 0.99$ & $21.05 \pm 0.78$ \\
$\mathrm{ORP}(\mathrm{mV})$ & $-283.16 \pm 37.75$ & $-262.26 \pm 47.75$ & $-243.78 \pm 23.7$ & $-236.98 \pm 27.07$ & $-243.51 \pm 41.03$ \\
$\mathrm{DO}(\mathrm{mg} / \mathrm{L})$ & $0.173 \pm 0.12$ & $0.173 \pm 0.16$ & $0.0625 \pm 0.08$ & $0.047 \pm 0.061$ & $0.017 \pm 0.03$ \\
Alkalinity & $238.4 \pm 52.3$ & $238.4 \pm 56.71$ & $156.25 \pm 22.16$ & $131.33 \pm 19.7$ & $145.88 \pm 22.16$ \\
$(\mathrm{mg} / \mathrm{LCaCO})$ & $239.5 \pm 76.2$ & $230.46 \pm 95.96$ & $144.92 \pm 50.92$ & $117.67 \pm 37.2$ & $115.22 \pm 34.01$ \\
Total COD(mg/L) & $144.72 \pm 66.2$ & $154.71 \pm 59.04$ & $91.19 \pm 29.47$ & $85.87 \pm 24.7$ & $82.09 \pm 15.92$ \\
SolubleCOD(mg/L) & $95.5 \pm 12.72$ & $70.25 \pm 4.59$ & $77.75 \pm 15.90$ & $113.5 \pm 2.12$ & $78 \pm 2.82$ \\
SolubleBOD5 & $144.8 \pm 43.10$ & $154.50 \pm 33.5$ & $114.80 \pm 31.5$ & $154.89 \pm 42.7$ & $144.51 \pm 18.73$ \\
$(\mathrm{mg} / \mathrm{L})$ & $12.72 \pm 26.76$ & $23.53 \pm 16.02$ & $5.91 \pm 5.08$ & $20.58 \pm 16.52$ & $5.79 \pm 4.31$ \\
Total carbon $(\mathrm{mg} / \mathrm{L})$ & $768.6 \pm 112.6$ & $765.5 \pm 198.06$ & $629.34 \pm 196.46$ & $717.34 \pm 95.44$ & $824 \pm 35.55$ \\
Organic carbon & $608 \pm 141.2$ & $603.17 \pm 165.25$ & $458.67 \pm 144.57$ & $602.67 \pm 60.17$ & $656 \pm 32$ \\
$(\mathrm{mg} / \mathrm{L})$ & $160 \pm 25.7$ & $162.31 \pm 33.56$ & $170.67 \pm 60.04$ & $114.67 \pm 43.87$ & $168 \pm 10.58$ \\
TS $(\mathrm{mg} / \mathrm{L})$ & & &
\end{tabular}

Total COD removal ranged from $50 \%$ at 4 hours HRT to $75 \%$ at 12 hours HRT. Similar results were obtained with BOD and TSS. According to Giraldo et al. (2007), average removals of COD, BOD and TSS in UASB reactors installed in Latin America ranged from 56\% - 79\%, 45\% - 81\% and 45\% - 81\%, respectively. Thus, the results obtained in this study showed that UASB performance was acceptable and comparable to the reports in the literature. However, it is important to point out that a post treatment of UASB effluent is needed to meet secondary and advanced treatment standards. Current full-scale installations in developing countries strive low cost and simplicity and typically have only screening and grit removal for pretreatment, and wetlands or aerobic or facultative lagoons for posttreatment (WEF et al., 2010).

A paired sample Student's t-test carried out with the COD removal obtained under the four HRT studied, revealed a significant difference with the results obtained at 12 hours HRT; hence, this HRT is recommended for the design of UASB at full-scale.

\subsection{Determination of rate constant $(\mathbf{K})$}

As mentioned in section 2.3, plotting the $\mathrm{S}_{\mathrm{t}}$ values on $x$-axis and $\frac{S_{i}-S_{t}}{x \theta_{i}}$ on $y$-axis, will give a straight with a slope equal to the rate constant $(\mathrm{K})$. A summary of the data employed to calculate $\mathrm{K}$ using the values of soluble $\mathrm{BOD}_{5}$ is given in Table 3 and the linear fit of this data is depicted in figure 1. On the other hand, the data employed to calculate K using the values of soluble COD is given in Table 4 and plotted in figure 2. 
Table 3.

Data from UASB reactor operated under four different HRT used to calculate $K$ with soluble $\mathrm{BOD}_{5}$ as substrate

\begin{tabular}{cccc}
\hline $\begin{array}{c}\text { HRT } \\
(\mathbf{d})\end{array}$ & $\begin{array}{c}\mathbf{S i - S t} \\
(\mathbf{m g} / \mathbf{L} \\
\text { soluble BOD })\end{array}$ & $\begin{array}{c}\frac{\boldsymbol{s}_{\boldsymbol{i}}-\boldsymbol{S}_{\boldsymbol{t}}}{\boldsymbol{X \boldsymbol { \theta } _ { \boldsymbol { i } }}} \\
(\mathbf{m g ~ B O D 5} / \mathbf{m g} \text { VSS-d })\end{array}$ & $\begin{array}{c}\mathbf{S t} \\
(\mathbf{m g} / \mathbf{L} \\
\text { soluble BOD })\end{array}$ \\
\hline 0.17 & 78 & 0.00789 & 103.5 \\
0.25 & 94.5 & 0.00664 & 90.0 \\
0.33 & 103.5 & 0.00570 & 77.7 \\
0.50 & 136.75 & 0.00526 & 70.2 \\
\hline
\end{tabular}

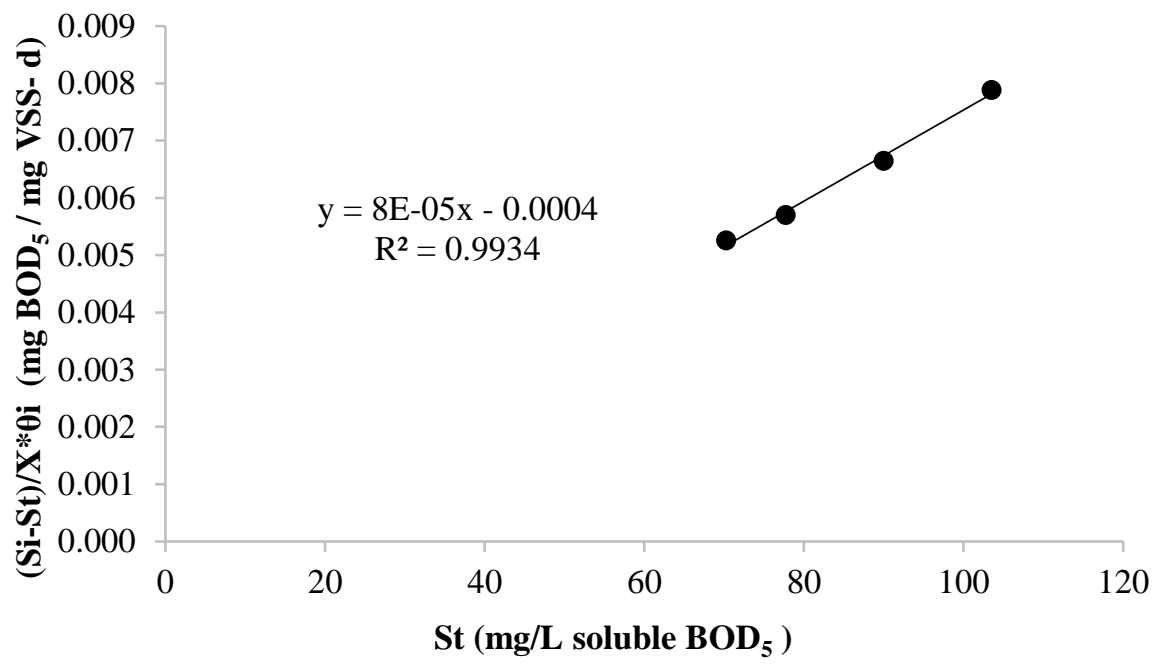

Figure 1. Linear fit for rate constant (K) calculation with soluble BOD 5 as substrate Table 4.

Data from UASB reactor operated under four different $H R T$ used to calculate $K$ with soluble COD as substrate

\begin{tabular}{|c|c|c|c|}
\hline $\begin{array}{c}\text { HRT } \\
\text { (d) }\end{array}$ & $\begin{array}{c}\mathrm{Si}-\mathrm{St} \\
(\mathrm{mg} / \mathrm{L} \text { soluble COD) }\end{array}$ & $\begin{array}{c}\frac{S_{i}-S_{t}}{X \theta_{i}} \\
(\mathrm{mg} \mathrm{COD} / \mathrm{mg} \mathrm{VSS-d})\end{array}$ & $\begin{array}{c}\mathrm{St} \\
(\mathrm{mg} / \mathrm{L} \text { soluble COD) }\end{array}$ \\
\hline 0.17 & 91.8 & 0.00928 & 144.7 \\
\hline 0.25 & 122.7 & 0.00862 & 105.2 \\
\hline 0.33 & 155.1 & 0.00854 & 98.9 \\
\hline 0.50 & 194.1 & 0.00746 & 82.1 \\
\hline
\end{tabular}




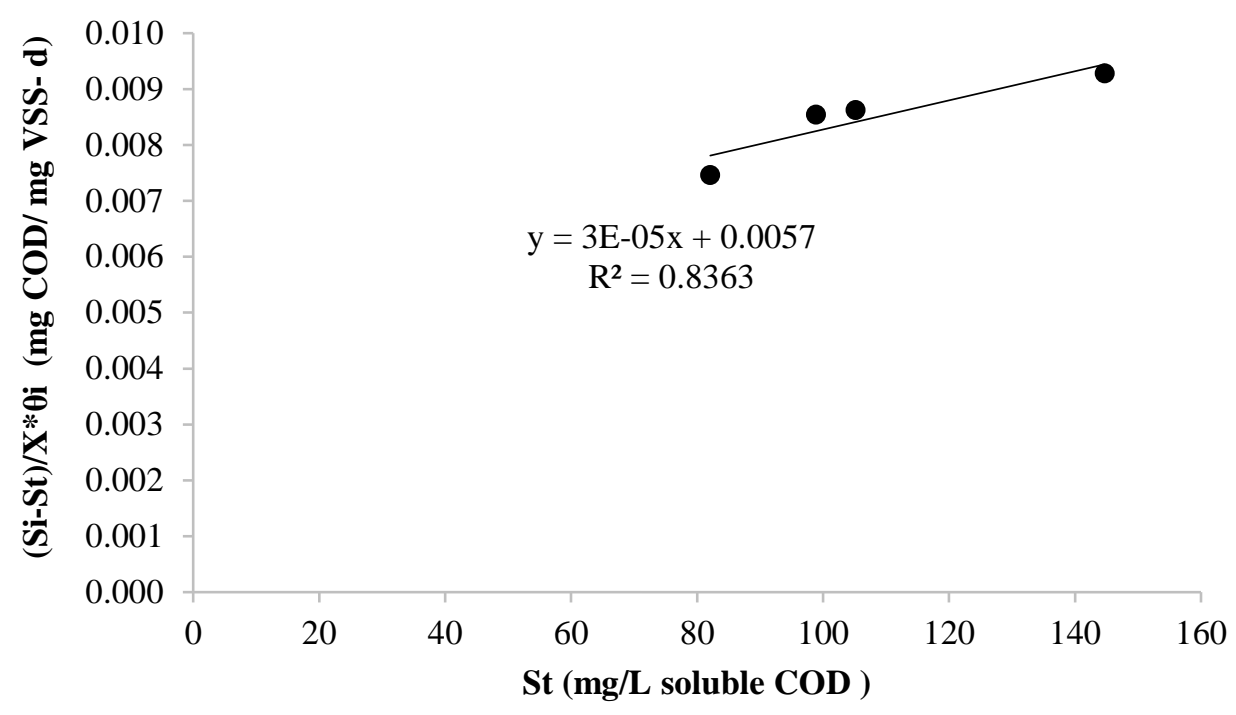

Figure 2. Linear fit for rate constant $(\mathrm{K})$ calculation with soluble COD as substrate

Since in the municipal wastewater from this experiment there are numerous substrates present, the rate constant $(\mathrm{K})$ represent an overall average value. As shown in figures 1 and 2 , the rate constant $(\mathrm{K})$ at $21^{\circ} \mathrm{C}$ for the municipal wastewater from UAM-Azcapotzalco campus is $8 \times 10^{-5} \mathrm{~L} / \mathrm{mg} \mathrm{VSS}-\mathrm{d}$ based on soluble BOD 5 and $3 \times 10^{-5} \mathrm{~L} / \mathrm{mg}$ VSS - $\mathrm{d}$ based on soluble COD.

The value of the rate constant $(\mathrm{K})$, depends primarily on the nature, complexity and composition of the wastewater, because the species of organic substrates will vary for different wastewaters (Reynolds \& Richards, 1996). In particular, for municipal wastewaters containing significant amounts of chemical wastes, which is the case of the municipal wastewater from the campus of UAM-Azcapotzalco, as the sewage system collects the wastewaters from laboratories.

Besides, as only certain microbial species in an acclimated sludge con bio-oxidize a particular organic compound and because each species has its own particular rate of utilization, it follows that the overall rate constant $(\mathrm{K})$ will vary for different types of wastewaters; even for municipal wastewaters, as the sewage systems could collect different organic compounds. In general, municipal wastewater has substrates more easily degraded that any of the industrial wastewater, although this is not always true. Thus, $\mathrm{K}$ values will be higher in municipal wastewaters than in the most industrial wastewaters.

Based on limited data, the rate constant $(\mathrm{K})$, for municipal wastewaters ranges from 0.10 to $1.25 \mathrm{~L} / \mathrm{mg} \mathrm{SS}-\mathrm{h}$ using total (soluble and insoluble) BOD5 as a measure of organic content (Lin, 1989; Reynolds \& Richards, 1996; Kalyuzhnyi \& Davlyatshina, 1997; Pérez et al., 1999; Montalvo \& Guerrero, 2003). To compare the values 
obtained in the present experiment with the values reported in scientific literature is difficult since temperature conditions were not the same and, also, the constants reported can be based on SS or VSS and different types of substrate (Total and soluble COD, $\mathrm{BOD}_{5}$ and TOC). Nevertheless, the rate constant values found are low, which indicates that in the municipal wastewater studied exists a large quantity of organic compounds hardly degraded, probably coming from the wastewater generated in the university laboratories.

This fact emphasizes the importance of choosing a $\mathrm{K}$ value for UASB reactor design, since exists a wide range in $\mathrm{K}$ values; for this reason, is important to carry out experiments in order to obtain the rate constant $(\mathrm{K})$.

\subsection{Determination of kinetic coefficients ( $Y$ and $\left.k_{e}\right)$}

As mentioned in section 2.3, plotting the $\left(\frac{S_{i}-S_{t}}{X \theta_{i}}\right)$ values on $x$-axis and $\frac{\Delta X / \Delta t}{X}$ on $y$-axis, will give a straight line with the slope equal to the cell yield coefficient $(\mathrm{Y})$ and $y$-axis intercept equal to the endogenous decay coefficient $\left(\mathrm{k}_{\mathrm{e}}\right)$. A summary of the data employed to calculate $\mathrm{Y}$ and $\mathrm{k}_{\mathrm{e}}$ using the values of soluble $\mathrm{BOD}_{5}$ is given in Table 5 and the linear fit of this data is depicted in figure 3. The data employed to calculate $\mathrm{Y}$ and $\mathrm{k}_{\mathrm{e}}$ using the values of soluble COD is given in Table 6 and plotted in figure 4.

The kinetic coefficients based on $\mathrm{BOD}_{5}$ as substrate obtained were $\mathrm{Y}=0.0427 \mathrm{mg} \mathrm{VSS} / \mathrm{mg} \mathrm{BOD}$ and $_{\mathrm{e}}=0.02 \mathrm{~d}^{-1}$; and the kinetic coefficients based on CODas substrate were $\mathrm{Y}=0.0596 \mathrm{mg} \mathrm{VSS} / \mathrm{mg}$ COD and $\mathrm{k}_{\mathrm{e}}=0.04 \mathrm{~d}^{-1}$.

Because the energetics of anaerobic processes results in lower biomass production by a factor of 6 to 8 times compared with aerobic processes, consequently, the biomass yield and decay are lower.

Tchobanoglous et al. (2003) stated that for anaerobic digestion of municipal wastewater, the values of the cell yield coefficient (Y) reported in literature ranged from 0.05 to $0.10 \mathrm{mg} \mathrm{VSS} / \mathrm{mg} \mathrm{COD}$, with a typical value of $0.08 \mathrm{mg}$ VSS/ mg COD, while Qasim (1999) reports values of the cell yield coefficient (Y) from 0.04 to $0.10 \mathrm{mg}$ VSS/ mg $\mathrm{BOD}_{5}$, with a typical value of $0.06 \mathrm{mg} \mathrm{VSS} / \mathrm{mg} \mathrm{BOD} 5$.

On the other hand, the values of the endogenous decay coefficient $\left(\mathrm{k}_{\mathrm{e}}\right)$ ranged from 0.02 to $0.04 \mathrm{~d}^{-1}$, with a typical value of $0.03 \mathrm{~d}^{-1}$ (Tchobanoglous et al., 2003). Therefore, the kinetic coefficients (Y and $\mathrm{k}_{\mathrm{e}}$ ) obtained in this experiment are in the interval reported in literature, although are bellow of those considered typical from municipal wastewater.

This result is in accordance with the values obtained for the rate constant $(\mathrm{K})$, which showed that the municipal wastewater employed in this experiment had hardly degraded organic material; and, as the new cells generated are proportional to the portion of substrate degraded, with a substrate with hardly degraded material, the cell yield will 
be lower. These lower values of the kinetic coefficients resulted in a less biological sludge production during the experiment (an increase of 5\% after six months of operation, regarding initial biomass in UASB reactor), which in full-scale operation represents a decrease in handling and hauling costs, yielding savings of approximately $10 \%$ compared to aerobic process (Speece, 1996).

Table 5.

Data from UASB reactor operated under four different HRT used to calculate $Y$ and $k_{e}$ with soluble $\mathrm{BOD}_{5}$ as substrate

\begin{tabular}{|c|c|c|c|c|}
\hline $\begin{array}{c}\text { HRT } \\
\text { (d) }\end{array}$ & $\begin{array}{c}\mathrm{Si}-\mathrm{St} \\
(\mathrm{mg} / \mathrm{L} \text { soluble BOD5) }\end{array}$ & $\begin{array}{c}\text { St } \\
\text { (mg/L soluble } \\
\text { BODs) }\end{array}$ & 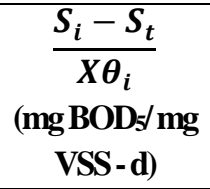 & $\begin{array}{c}(\Delta \mathbf{X} / \Delta \mathbf{t}) / \mathbf{X} \\
\left(\mathbf{d}^{-1}\right)\end{array}$ \\
\hline 0.17 & 78 & 103.5 & 0.00789 & 0.000137 \\
\hline 0.25 & 94.5 & 90 & 0.00664 & 0.000103 \\
\hline 0.33 & 103.5 & 77.75 & 0.00570 & 0.000049 \\
\hline 0.50 & 136.75 & 70.25 & 0.00526 & 0.000026 \\
\hline
\end{tabular}

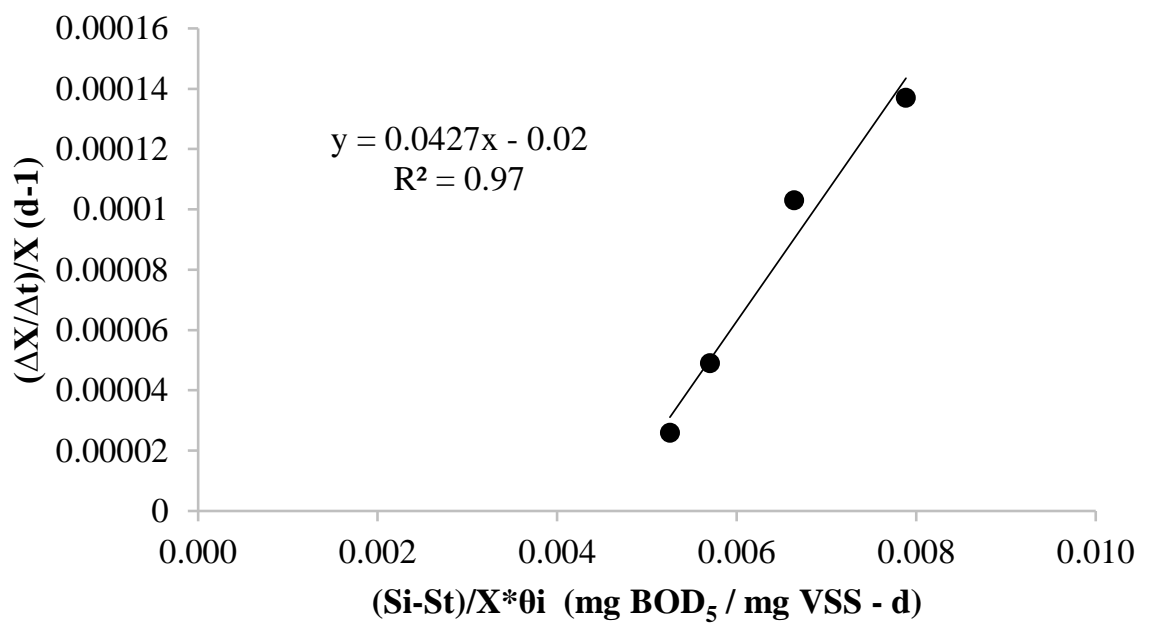

Figure 3. Linear fit for cell yield coefficient $(\mathrm{Y})$ and endogenous decay coefficient $\left(\mathrm{k}_{\mathrm{e}}\right)$ calculation with soluble $\mathrm{BOD}_{5}$ as substrate 
Table 6.

Data from UASB reactor operated under four different HRT used to calculate $Y$ and $k_{e}$ with soluble COD as substrate

\begin{tabular}{ccccc}
\hline $\begin{array}{c}\text { HRT } \\
(\mathbf{d})\end{array}$ & $\begin{array}{c}\text { Si-St } \\
(\mathbf{m g} / \mathbf{L} \text { soluble COD) }\end{array}$ & $\begin{array}{c}\mathbf{S t} \\
(\mathbf{m g} / \mathbf{L} \text { soluble COD) }\end{array}$ & $\begin{array}{c}\frac{\boldsymbol{S}_{\boldsymbol{i}}-\boldsymbol{S}_{\boldsymbol{t}}}{\boldsymbol{X} \boldsymbol{\theta}_{\boldsymbol{i}}} \\
(\mathbf{m g ~ C O D} / \mathbf{m g} \\
\mathbf{V S S}-\mathbf{d})\end{array}$ & $\begin{array}{c}(\mathbf{\Delta X} / \Delta \mathbf{t}) / \mathbf{X} \\
\left(\mathbf{d}^{-1}\right)\end{array}$ \\
\hline 0.17 & 91.8 & 144.7 & 0.00928 & 0.000137 \\
0.25 & 122.7 & 105.2 & 0.00862 & 0.000103 \\
0.33 & 155.1 & 98.9 & 0.00854 & 0.000049 \\
0.50 & 194.1 & 82.1 & 0.00746 & 0.000026 \\
\hline
\end{tabular}

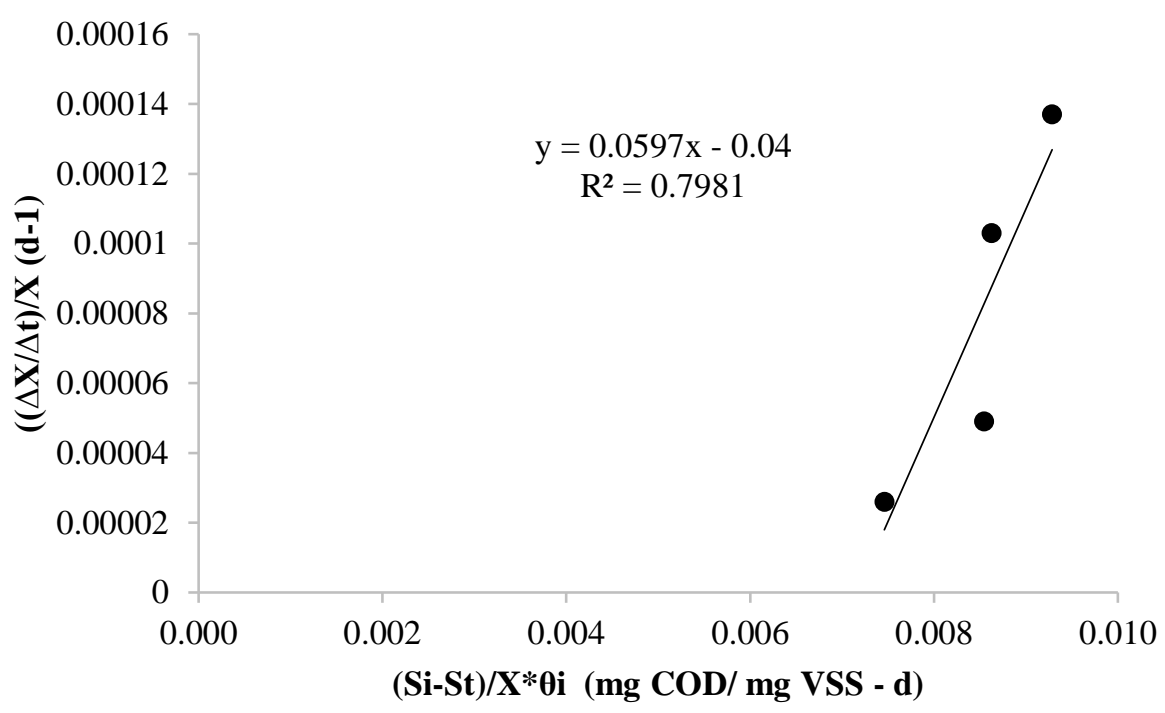

Figure 4. Linear fit for cell yield coefficient $(\mathrm{Y})$ and endogenous decay coefficient $\left(\mathrm{k}_{\mathrm{e}}\right)$ calculation with soluble COD as substrate

\subsection{Determination of the mean cell residence time in UASB reactor}

In order to determine $\theta_{\mathrm{C}}$ of the UASB reactor, was employed the equation 2.12 presented in section 2.4. In this equation was considered that the TSS production per day ( $\mathrm{X}_{\mathrm{T}, \mathrm{SST}}$ ) was equal to TSS concentration in the UASB reactor effluent, due to during the experiment was not to carry out any discharge of sludge.

Equation 2.12 was solved for $\theta_{\mathrm{C}}$ using the coefficients $\mathrm{Y}=0.0427 \mathrm{mg}$ VSS $/ \mathrm{mg} \mathrm{BOD}_{5}$ and $\mathrm{k}_{\mathrm{e}}=0.02 \mathrm{~d}^{-1}$, obtained in section 3.3 using $\mathrm{BOD}_{5}$ as substrate. These coefficients were chosen since the linear fit had a higher linear correlation coefficient $\left(\mathrm{R}^{2}\right)$. Also, were employed the results of $\mathrm{BOD}_{5}$ obtained in the UASB reactor influent and effluent during the experiment, finding a $\theta_{\mathrm{C}}$ value for each HRT studied. The data employed and results of $\theta_{\mathrm{C}}$ are shown in table 7. 
Table 7.

Data from UASB reactor operated under four different HRT used to calculate the mean cell residence time $\left(\theta_{C}\right)$ using the kinetic constants obtained with soluble $\mathrm{BOD}_{5}$ as substrate

\begin{tabular}{ccccc}
\hline $\begin{array}{c}\text { HRT } \\
(\mathbf{d})\end{array}$ & $\begin{array}{c}\text { (Si-St) } \\
\mathbf{m g} / \mathbf{L} \text { soluble } \\
\text { BOD5 }\end{array}$ & $\begin{array}{c}\text { Effluent TSS } \\
(\mathbf{m g} / \mathbf{L})\end{array}$ & $\begin{array}{c}\text { Nonbiodegradable TSS in } \\
\text { effluent }(\mathbf{m g} / \mathbf{L})\end{array}$ & $\begin{array}{c}\text { 0c } \\
\text { (d) }\end{array}$ \\
\hline 0.17 & 78.0 & 824.00 & 164.8 & 49.0 \\
0.25 & 94.5 & 717.33 & 143.5 & 49.7 \\
0.33 & 103.5 & 629.33 & 125.9 & 49.6 \\
0.50 & 136.7 & 765.50 & 153.2 & 49.6 \\
\hline
\end{tabular}

Mean cell residence time in the UASB reactor at lab scale was 49.5 days. The cell residence time is a fundamental design and operating parameter for all anaerobic processes (van Haadel et al., 2006).

In general, $\theta_{\mathrm{C}}$ values greater than 20 days are needed for anaerobic processes at $30{ }^{\circ} \mathrm{C}$ for effective treatment performance, with much higher $\theta_{\mathrm{C}}$ values at lower temperatures (Tchobanoglous et al., 2003). However, the $\theta_{\mathrm{C}}$ found in this experiment was short, if is considered the suggestion of Henze et al. (2008), who recommended a $\theta_{\mathrm{C}}$ of approximately 95 days at $20{ }^{\circ} \mathrm{C}$ for domestic wastewater treatment. For this reason, when $\theta_{\mathrm{C}}$ is determined using kinetic coefficients, is recommendable to use a safety factor of 1.5 in UASB reactor design, this fact will permit a very stable performance and a short restauration after a shut down for extended periods of time (up to several

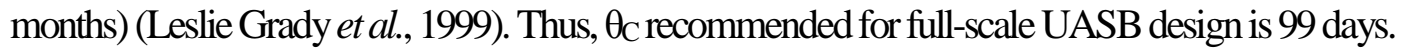

\section{CONCLUSION}

The UASB reactor is a sustainable technology for the treatment of municipal wastewater generated at the Universidad Autónoma Metropolitana - Azcapotzalco campus, since adequate levels of COD, $\mathrm{BOD}_{5}$ and TSS removal were achieved, ranged from $50 \%$ at 4 hours HRT to $75 \%$ at 12 hours HRT. A paired sample Student's ttest carried out with the COD removal obtained under the four HRT studied, revealed a significant difference with the results obtained at 12 hours HRT; hence, this HRT is recommended for full-scale UASB design. The rate constant $(\mathrm{K})$ at $21^{\circ} \mathrm{C}$ was $8 \times 10^{-5} \mathrm{~L} / \mathrm{mg}$ VSS $-\mathrm{d}$ based on soluble $\mathrm{BOD}_{5}$ and $3 \times 10^{-5} \mathrm{~L} / \mathrm{mg} \mathrm{VSS}-\mathrm{d}$ based on soluble COD, values considered low; which indicates the presence of a large quantity of organic compounds hardly degraded, probably coming from the wastewater generated in the university laboratories. The kinetic coefficients were $\mathrm{Y}=0.0427 \mathrm{mg} \mathrm{VSS} / \mathrm{mg} \mathrm{BOD}_{5}$ and $\mathrm{k}_{\mathrm{e}}=0.02 \mathrm{~d}^{-1}$ based on soluble $\mathrm{BOD}_{5}$ as substrate and $\mathrm{Y}=0.0596 \mathrm{mg}$ $\mathrm{VSS} / \mathrm{mg}$ COD and $\mathrm{k}_{\mathrm{e}}=0.04 \mathrm{~d}^{-1}$ based on soluble COD as substrate. Mean cell residence time $\left(\theta_{\mathrm{C}}\right)$ in the UASB 
reactor at lab scale was 49.5 days; although, $\theta_{\mathrm{C}}$ recommended for full-scale UASB design is 99 days, this value will permit a very stable performance and a short restauration after a shut down for an extended period of time.

\section{ACKNOWLEDGEMENTS}

The authors acknowledge PROMEP for funding, through the "Red de Tecnología del Agua” project.

\section{Bibliography}

APHA, AWWA, WEF, (1998), Standard methods for the examination of waste and wastewater, 20th ed, Washington DC, USA: American Public Health Association.

Foresti, E., Zaiat, M., Vallero, M. (2006). Anaerobic Processes as the Core Technology for Sustainable Domestic Wastewater Treatment: Consolidated Applications, New Trends, Perspectives, and Challenges. Rev. Environ. Sci. Bio/Technol., 5(1), 3-19.

Galli. R., McCarty, P.L. (1989). Biotransformation of 1,1,1-trichloroethane, trichloromethane and tetrachioromethane by a Clostridium sp., Appl. Environ. Microbiol., 55(5),837-44.

Giraldo, E., Pena, M., Chernicharo, C., Sandino, J., Noyola, A. (2007). Anaerobic sewage treatment technology in Latin-America: A selection of 20 years of experiences. Proceedings of the 80th annual water environment federation exposition and conference, San Diego, California; WEF.

Henze, M., Van Loosdrecht, M.C.M., Ekama, G.A., Brdjanovic D., (2008), Biological Wastewater Treatment Principles, Modeling and Design, London, England: IWA Publishing.

Kalyuzhnyi, S., Davlyatshina, M. (1997). Batch anaerobic digestion of glucose and its mathematical modeling. Kinetic investigations, Biores. Technol., 59(1),73-80.

Khan, A., Gaur, R., Tyagi, V.K., Khursheed, A., Lew, B., Mehrotra, I., Kazmi, A.A. (2011) Sustainable options of post treatment of UASB effluent treating sewage: A review. Resour., Conserv. Recycl., 55(12),1232-1251.

Leslie Grady Jr, C.P. , Daigger, G.T., Lim H.C., (1999), Biological Wastewater Treatment, 2nd ed, Boca Raton, USA: CRC Press

Lin, C., Noike, T., Furumai, H., Matsumoto, J. (1989). A kinetic study on the methanogenesis process anaerobic digestion, Water Sci. Technol., 21(1),175-186. 
Montalvo, S., Guerrero, L., (2003), Tratamiento anaerobio de residuos. Valparaíso, Chile: Universidad Técnica Federico Santa María.

Pérez, J., Fernández, N., Herrera, M., Galindo, A., Toncel, E., Rojano, R., Daza, S. (1999). Diseño de un sistema UASB y lagunas de estabilización para tratar los desechos líquidos de una industria procesadora de Camarones, Rev. Tec. Ing. Univ. Zulia, 2(1),194 -204.

Qasim, S.Y., (1999), Wastewater treatment plants. Planning, design and operation, 2nd ed., Boca Raton, USA: CRC press.

Reynolds, T. D., Richards P. A., (1996), Unit Operations and Processes in Environmental Engineering, 2nd ed, Boston, USA: PWS Publishing Company.

Soto. M., Méndez, R., Lema. J. (1993). Methanogenic and non-methanogenic activity tests. Theoretical basis and experimental set-up, Water Res., 27(8),1361-76.

Speece, R.E., (1996), Anaerobic biotechnology, Nashville, USA: Archae press.

Tchobanoglous, G., Burton, F.L., Stensel, H.D., (2003), Wastewater Engineering: Treatment and Reuse, 4th ed., Reston, USA: McGraw-Hill.

Van Haandel, A,C., Lettinga, G., (1994), Anaerobic sewage treatment: a practical guide for regions with hot climate, Chichester, England: John Wiley and Sons.

Water Environment Federation (WEF), American Society Of Civil Engineergs (ASCE), Environmental \& Water Resources Institute (EWRI), (2010), Design of municipal wastewater treatment plants, 5th ed., Reston, USA: McGraw Hill. 